Article

\title{
Job Loss in a Group of Older Canadian Workers: Challenges in the Sustainable Labour Market Reintegration Process
}

\author{
Geneviève Fournier ${ }^{1}$ *, Hélène Zimmermann ${ }^{1}$, Jonas Masdonati ${ }^{2} \mathbb{D}$ and Christine Gauthier 1 \\ 1 Département des Fondements et Pratiques en Éducation, Centre de Recherche sur l'Intervention \\ Et la Vie Au Travail (CRIEVAT), Faculté des Sciences de l'Éducation, Laval University, \\ Québec City, QC G1V 0A6, Canada; helene.zimmermann@fse.ulaval.ca (H.Z.); \\ christine.gauthier@fse.ulaval.ca (C.G.) \\ 2 Institute of Psychology, Research Center in Vocational Psychology and Career Counseling (CePCO), \\ University of Lausanne, CH-1015 Lausanne, Switzerland; Jonas.Masdonati@unil.ch \\ * Correspondence: genevieve.fournier@fse.ulaval.ca; Tel.: +1-418-656-2131 (ext. 3379)
}

Received: 23 May 2018; Accepted: 26 June 2018; Published: 29 June 2018

\begin{abstract}
In Western countries, the loss of jobs among older workers is a highly worrisome situation, since it can be synonymous with long-term employment precariousness and definitive exclusion from the labour market. This precariousness is occurring while the labour force in these countries is aging, and governments are looking to extend people's working lives. It is therefore particularly relevant to study different labour market reintegration processes and to understand their sustainability from a psychological perspective. The present article is examining these processes using a longitudinal study over an 18-month period with 61 older Canadian workers. Time 1 and Final Time were documented with semi-structured individual interviews. These data allowed us to qualitatively construct three reintegration processes (blocked, downgrading, and sustainable) that describe a large spectrum of workers' experiences regarding occupational repositioning. Quantitative analyses likewise suggest moderate statistical links between the reintegration process and changes in subjective variables associated with the relationship to work and identity representations. Altogether, the results underline the importance of returning to the labour market in qualified, decent, sustainable work that allows people to have a decent and meaningful personal life. The results also suggest, in keeping with the psychology of sustainability, that interventions should promote occupational and personal enrichment, both at the individual and organizational levels.
\end{abstract}

Keywords: psychology of sustainability and sustainable development; sustainable career; decent work; positive career outcomes; unemployment; older workers; labour market reintegration; relationship to work; identity representations

\section{Introduction}

In the last few decades, the globalization of markets, increasing competition, and the advent of a knowledge-based economy have brought about considerable changes in the production system and organization of work [1]. Human resource practices have become more flexible [2,3]. The types of employment labelled non-standard or precarious $[4,5]$, which are characterized by more unstable ties to work, are becoming increasingly common. A greater number of workers are now on precarious career paths that create numerous impediments to long-term integration into the labour market [6-9]. Older workers no longer benefit from the protection that accumulated experience in the labour market once provided and are now at greater risk of unemployment $[10,11]$. In Western countries, the loss of a job at this stage in life can be synonymous with long-term economic precariousness 
that can end in definitive exclusion from the labour market $[12,13]$. This highly worrisome situation is occurring at the same time as the labour forces in North America and Europe is aging and their governments are looking to extend people's working lives [14-16]. The psychology of sustainability and sustainable development proposed by Di Fabio $[2,3,17]$ highlights the value of a primary prevention approach [18-20] and the interest of closely examining different labour market reintegration processes and their sustainability from a psychological perspective.

The present article looks at the process of labour market reintegration for unemployed workers 45 years old and over. (The definition of "older workers" varies according to the source and context. In this article, it includes all workers 45 years old and over, based on Québec [21] and Canadian [22] policies.) It is based on the results of a longitudinal study conducted over an 18-month period with 61 older workers in the Province of Québec (Canada).

\subsection{Labour Market Reintegration for Older Workers: Issues and Obstacles}

In Canada, as in other Western countries, the reintegration into the labour market of unemployed older workers has its own particular difficulties. Statistics on the subject reveal that, while the workers in this age category are less affected by job losses than are younger people, they are far from being spared [23,24]. In the Province of Québec, from 2006 to 2016, the percentage of unemployed workers who were 55 years old and over increased considerably from $11.7 \%$ to $18.1 \%$ [25]. Furthermore, older workers are particularly affected by long-term unemployment (one year and more). For example, among Canadians who are let go due to economic redundancy, the probability of finding another job within the year is $14 \%$ lower in the 55-64-year-old category than it is in the 25-34 group [23]. Additionally, when unemployed older workers do succeed in re-entering the labour market, the jobs they find are often synonymous with both precariousness and occupational downgrading [26] and are marked by a considerable decrease in revenue [27-30]. In this context, it is not surprising that unemployed older workers have a more pessimistic view of their future in the job market than do younger people [30].

What is more, older workers must deal with specific obstacles in their reintegration. Some are personal in nature and have to do with their employability or job hunting strategies [11]. Among the most prejudicial factors regarding the employability of older workers are advanced age, low education level, and poor health [31,32]. Other obstacles are of a contextual nature and can stem from the gap between the abilities required in the job market and those older workers actually have [33]. They also comprise the undervaluing of older workers [34], a practice also known as ageism that involves systematic stereotyping [35]. Older workers are seen to be less flexible and less productive, to have obsolete skill sets, and to be too expensive for the company [11], making them susceptible to de facto discrimination in the labour market [36]. This discrimination considerably reduces their possibilities of returning to the labour market in qualified, decent, and sustainable work [31], that is, employment that makes sense to them, meets objective work quality criteria, and allows people to have a decent and meaningful personal life [19,37-44]. The many obstacles encountered in reintegration come in addition to the fundamental difficulty of losing one's job in one's late 40s. The relation to work can thus be profoundly modified.

\subsection{Job Loss and Relationship to Work}

The relationship to work is a complex notion that comprises several dimensions [45-52]. Two of them in particular make operationalization possible, namely, the purposes of work and work's relative importance compared to the other spheres of life.

The purposes of work refer to the general goals that people pursue through work and the main values they want to actualize through this activity. These goals and values help to give meaning to their work. It is likewise on their goals and values that people base their choices and decisions [50]. Most authors have identified different purposes that can be classified dichotomically, even though they are sometimes hard to tell apart [45]. On the one hand, the purposes of work 
that are "expressive" [49,51,53], "experiential" [47], and "intrinsic" [48,54] are related to people's personal and social development (e.g., self-fulfilment). On the other hand, "instrumental", "economic", and "extrinsic" purposes $[47,49,53]$ concern the more utilitarian aspects of work (e.g., something to do).

The relative centrality of work consists in the value or importance that this sphere of activity is accorded compared to other spheres in life. Work can thus have a primary, equal, or secondary importance in people's lives. Moreover, the relative importance of work can vary according to people's recent work experiences, the occupational context in which they work, and their current priorities or stage in life [8,46,55-58]. Finally, it would seem that older workers generally accord higher relative importance to work than do younger workers, and that they also tend to be more committed to the sphere of work than their younger colleagues [47,53,59].

Moreover, confronted with reintegration difficulties, older workers may reduce the relative importance they attribute to work $[60,61]$ and assign a more utilitarian purpose to it. For some, it is a question of serenely accepting the fact that they are getting older, nurtured by the feeling of entering a new stage in life and the desire to invest more energy in activities other than work [62]. For others, the psychological withdrawal can prove to be "painful" when work has always been the main source of personal investment and is still perceived as a wonderful opportunity for personal achievement [13]. It can also be psychologically costly when people must stay in the labour market for several years [63] and feel like they are caught in a trap: too old to be attractive to employers, too young for retirement [34]. In both cases, the decrease in the relative importance of work can be interpreted as a strategy that is set in motion by unemployed older workers to preserve their self-esteem and identity cohesion [60,64-66].

\subsection{Relationship to Work and Identity Construction}

Numerous studies have shown that the more importance people attach to work, the more (1) this sphere of activity represents a source of fulfilment that contributes to their identity and personal development, and the more (2) these people are likely to identify with their work [53,55,67-69]. Accordingly, the unemployed older workers for whom identity destabilization is likely to be the most severe are those for whom work is a central pillar of identity, the place in their life in which they most invest $[65,70,71]$. Consequently, the meaning that the loss of a job represents can vary from one case to another and affect different aspects of a worker's identity. This identity or "awareness of oneself as a worker" [72] (p. 693) integrates two aspects, namely the occupational identity and social identity, both interacting strongly with each other [73,74].

Occupational identity, that is the "personal definition of oneself for oneself" [73] (p. 389), constitutes the coherent representation that people have of themselves and their uniqueness as workers, with all their skills and values. This representation is expressed in other ways by one's occupational self-esteem [75] and by the feeling of having developed the appropriate skills for an occupation, a profession, or a field of activity [76,77]. As for social identity, that is the "definition of oneself for and by others" [73] (p. 389), it constitutes the workers' identification with a category, an occupational group, or an organization, as well as the recognition they receive from society and their employers [78-80]. When the gap is too big between how a worker defines him/herself and how others define this worker, the worker is likely to be confronted with an "identity crisis" [79] and a deterioration in his/her relationship to work.

\subsection{Identity Loss in Unemployed Older Workers}

The consequences of losing one's job in the last third of one's working life can be particularly deleterious at the psychological level and affect one's occupational and social identity [72,81,82]. As regards occupational identity, the self-esteem of unemployed older workers is often affected, their dignity attacked, and their abilities dismissed $[83,84]$, especially when they lose their financial independence due to a lack of employment revenue. Certain authors likewise evoke identity "fragmentation" [85,86] or an identity "rupture" [71] provoked by the gap between the image of experienced, competent people that older workers often have of themselves and that of hard-to-employ 
people that employers send back to them $[87,88]$. Moreover, when they lose their jobs, some older workers can feel betrayed by society and undermined in their value system $[26,84,86,89,90]$. This is particularly the case with those who began working in an economic growth context and who expect to be well treated due to their seniority.

With regard to their social identity, when older workers lose their job, they feel deprived of their worker status that helped to define them and allow them to be recognized by society [91]. Many of these workers have the impression they are no longer useful to a community that does not require their skills [92]. Moreover, the erosion of their network of former work colleagues and the financial precariousness associated with unemployment are likely to marginalize those who are already most isolated [66,70]. For a smaller number of workers, deprived of the socio-temporal framework that work provides and that structures their life in society, losing one's job can result in bona fide social alienation [11].

\subsection{Labour Market Reintegration as a Psychosocial Transition}

At the theoretical level, labour market reintegration is seen as a psychosocial transition, a pivotal moment, a rupture [93] between two stages in life that is likely to provoke major, long-lasting changes in one's representation of oneself and the world [94]. In this sense, this approach emphasizes how people see themselves and integrate these changes into their lives [95]. This approach also implies that transitions take place in the interactions between people and their environments [96], and that these transitions have intra-psychological, interpersonal, and contextual components.

In this approach, transitions are analyzed as a process with three complementary levels [97]. The first level is that of identity transformation and the changes in individual values that can accompany it [98-100]. In the present study, for example, this means understanding the extent to which people are led to redefine themselves as workers, depending on whether or not they feel that their skills and experience are acknowledged and that they still have a place in the labour market. This also involves understanding the extent to which reintegration is accompanied by a redefinition of one's priorities in life. The second level involves the actions initiated by workers to deal with changes [101-103]. This level looks at the strategies people use to reposition themselves in the job market (e.g., career shift, reconsideration of one's job expectations). It takes into account both their subjective experience and the contexts in which these strategies are implemented. The third level is that of people's (re)construction of meaning, which helps them maintain a stable self in the interactions between their past experiences, new situations, and personal projects [104-106]. The third level assumes an understanding of the meaning people give to their new position in the labour market, whether it be separated from or continuous with their previous path. It likewise supposes an understanding of their expectations for the future based on their representations of such things as their age, their stage in their working life, and the meaning of work.

Based on data from an 18-month longitudinal study, this article complements existing studies by examining, from a diachronic perspective and using a mixed-method approach, the labour market reintegration processes of workers who lost their employment at age 45 or over. More specifically, based on a qualitative method focused on people's experience, the article aims primarily to reconstruct these processes according to three dimensions: labour-market reintegration paths, relationship to work, and identity representations. At the same time, using a quantitative method, the article aims to shed light on the statistical links between (1) the reintegration process and (2) the subjective variables associated with the relationship to work and the participants' identity representations.

\section{Materials and Methods}

\subsection{Participants}

Sixty-six adults aged 45 and over participated in the whole longitudinal study. They were recruited through ads in the local press and employment assistance centres situated in Québec City and its surrounding region, in the Province of Québec, Canada. 
At the beginning of the study (T1), the researchers met with 110 workers who had been unemployed for less than 12 months. Eighteen months later (TF), the sample comprised 70 participants. The retention rate was thus $64 \%$, which is considered to be acceptable for populations that are difficult to contact [107]. Of the 70 participants who were followed all throughout the study, 61 were selected for the present article; those who at FT were either definitively out of the labour market due to retirement or temporarily due to training were not included.

The sample was comprised of 39 women (64\%) and 22 men (36\%). At T1, there were 23 participants (38\%) from 45 to 50 years old, 26 (43\%) from 51 to 55 , and 12 (20\%) 56 years old or more. With regard to their education, 22 (36\%) participants either had a high school diploma or no diploma at all, $17(28 \%)$ had a community college (CÉGEP) diploma, and 22 (36\%) had a university degree (the Province of Québec has CÉGEPs, which are post-secondary, general, and vocational community colleges. The general is 2 years and prepares students for university studies, and the vocational is 3 years and prepares students for an occupation (e.g., machinist) or a profession (e.g., nursing).). Workers who participated in the whole study and those who dropped out along the way did not differ significantly with regard to gender $\left(\chi^{2}{ }_{(1)}=1.082, p>0.05\right)$, age $\left(\chi^{2}{ }_{(1)}=4.082, p>0.05\right)$, and education $\left(\chi^{2}{ }_{(1)}=5.024\right.$, $p>0.05)$.

\subsection{Material}

The data collection was based on a "short-medium duration" longitudinal design [108], that is, 18 months split into four measurement times. For the purposes of the present article, only the Time 1 (T1) and final time (FT), documented with a semi-structured individual interview, were selected. The interviews were conducted in person at T1 (about $2 \mathrm{~h}$ in length) and on the phone at FT (about $1 \mathrm{~h}$ in length). To make comparisons easier, the two interview grids had the same, four-part structure: (1) an overview of the key events in the career path since the person entered the labour market and an examination of the job loss experience (T1), and an overview of the key events in the reintegration since the job loss (FT); (2) an examination of the employment situation at the time of the interview and the way the reintegration events were experienced and the meaning they took on; (3) predictions about their future possibilities in the job market; and (4) socio-occupational representations (e.g., stages in working life, relative importance of work). All the interviews were recorded and completely transcribed in an anonymized computer file.

\subsection{Analysis Procedure}

The data processing was based on the mixed method embedded design [109], which includes qualitative and quantitative analysis procedures. The aim is to quantify complex and nuanced qualitative data so as to add numerical precision [110]. Congruent with the first objective, the qualitative aspect distinguishes the different processes of labour market reintegration, combining the key events in the processes, some of the workers' representations, and, if need be, the change or stability between T1 and FT of a few of these representations. In keeping with the second objective, the quantitative part made it possible to determine the relations between (1) the identified processes and (2) the change or stability - from T1 to FT—of the variables associated with the relationship to work and the participants' identity representations.

\subsubsection{Qualitative Analysis Procedure}

The qualitative analysis procedure, which employed thematic content analysis [111], was conducted using an interpretative perspective that focused on the meaning that people gave to their experiences [112]. The analysis, inspired by L'Écuyer's method [113], was conducted in successive steps with an iterative approach [114], as recommended by the APA [115]. Three researchers worked together on the interview analysis using triangulation principles [116] and the "ethics of transparency" [115] (p. 29). 
The whole approach can be summarized into two main stages. An analysis grid was constructed in the first stage using an inductive approach based on emerging or reoccurring themes [111], which came up in the participants' comments about their integration into the labour market. A reading of the material collected from 21 of the participants allowed the three analysts to first bring together the identified themes under the three following structural dimensions: (I) the path that reintegration into the labour market took, (II) the changes in their relationship to work from the beginning to the end of this path (T1-FT), and (III) the changes in their identity representations (T1-FT). Due to the iterative data analysis and the addition of interview material, the researchers were then able to divide the three structural dimensions into nine sub-dimensions (A to I), which, put together, made it possible to describe the reintegration processes.

Dimension I: (A) sequence of events and changes in the reintegration path, (B) occupational situation after 18 months (FT), (C) main obstacles observed in the reintegration path, (D) occupational self-esteem at the end of the path (FT), and (E) expectations for their future in the labour market (FT).

Dimension II: (F) changes or stability in the relative importance of work with respect to other spheres in life (primary, equal, or secondary importance) and $(G)$ changes or stability in the dominant purpose of work (expressive or instrumental).

Dimension III: $(\mathrm{H})$ changes or stability in the representation of age in the labour market (seen as a strength, limitation, or obstacle for remaining in the labour market) and (I) changes or stability in representation of the stage in one's working life (feeling of being at the midpoint or the end of one's working life).

The three analysts then proceeded to separate the nine sub-dimensions into finer categories. By adding data from the interviews to the other 40 participants, the definitions of the nine sub-dimensions and their categories were reworked and fine-tuned using the "self-correcting process" [115] (p. 27). Two analysts divided the coding of the extracts; when difficult cases arose, they were arbitrated by a third analyst. In this way, all the data relative to the reintegration processes of the 61 participants were categorized using the analysis grid shown in Table 1 . This grid allowed us to draw up a general portrait of labour market reintegration as experienced by the participants.

Table 1. Analysis grid for the participants' reintegration process and distribution.

\begin{tabular}{|c|c|c|}
\hline Structural Dimensions & Sub-Dimensions & Categories \\
\hline \multirow{4}{*}{$\begin{array}{l}\text { I. Reintegration path in the } \\
\text { labour market }\end{array}$} & $\begin{array}{l}\text { A. Sequence of events and changes } \\
\text { in the reintegration path }\end{array}$ & $\begin{array}{l}\text { 1. Linear path }(n=23) \\
\text { 2. Winding path }(n=19) \\
\text { 3. Chaotic path }(n=19)\end{array}$ \\
\hline & $\begin{array}{l}\text { C. Main obstacles over the } \\
18 \text { months }\end{array}$ & $\begin{array}{l}\text { 1. Primarily individual obstacles }(n=9) \\
\text { 2. Primarily contextual obstacles }(n=10) \\
\text { 3. Accumulation of individual and contextual obstacles }(n=19) \\
\text { 4. Few or no obstacles encountered }(n=23)\end{array}$ \\
\hline & $\begin{array}{l}\text { D. Occupational self-esteem at the } \\
\text { end of the reintegration path (FT) }\end{array}$ & $\begin{array}{l}\text { 1. Positive occupational self-esteem }(n=35) \\
\text { 2. Negative occupational self-esteem }(n=26)\end{array}$ \\
\hline & $\begin{array}{l}\text { E. Expectations for their future in } \\
\text { the labour market (FT) }\end{array}$ & $\begin{array}{l}\text { 1. Resigned about an uncertain future in the job market }(n=39) \\
\text { 2. Serene, optimistic future in the job market }(n=22)\end{array}$ \\
\hline \multirow[t]{2}{*}{$\begin{array}{l}\text { II. Changes or stability in the } \\
\text { relationship to work (T1-FT) }\end{array}$} & $\begin{array}{l}\text { F. Changes or stability in the } \\
\text { relative importance of work }\end{array}$ & $\begin{array}{l}\text { 1. Stability in the relative importance of work }(n=37) \text { : } \\
\text { 1.1. Stable primary importance }(n=6) \\
\text { 1.2. Stable equal importance }(n=23) \\
\text { 1.3. Stable secondary importance }(n=8) \\
\text { 2. Decrease in the relative importance of work }(n=23) \text { : } \\
\text { 2.1. Primary to equal importance }(n=9) \\
\text { 2.2. Equal to secondary importance }(n=9) \\
\text { 2.3. Primary to secondary importance }(n=5)\end{array}$ \\
\hline & $\begin{array}{l}\text { G. Changes or stability in the } \\
\text { dominant purpose of work }\end{array}$ & $\begin{array}{l}\text { 1. Stability in dominant purpose of work }(n=41) \text { : } \\
\text { 1.1. Stable expressive purpose }(n=22) \\
\text { 1.2. Stable instrumental purpose }(n=19) \\
\text { 2. Changes in the dominant purpose of work }(n=20) \text { : } \\
\text { 2.1. Expressive to instrumental purpose }(n=16) \\
\text { 2.2. Instrumental to expressive purpose }(n=4)\end{array}$ \\
\hline
\end{tabular}


Table 1. Cont.

\begin{tabular}{|c|c|c|}
\hline Structural Dimensions & Sub-Dimensions & Categories \\
\hline \multirow[t]{2}{*}{$\begin{array}{l}\text { III. Changes or stability in } \\
\text { identity representations (T1-FT) }\end{array}$} & $\begin{array}{l}\text { H. Changes or stability in the } \\
\text { representation of age }\end{array}$ & $\begin{array}{l}\text { 1. Stability in the representation of age in the labour market }(n=28) \text { : } \\
\text { 1.1. Always perceived as a strength }(n=13) \\
\text { 1.2. Always perceived as a limitation }(n=12) \\
\text { 1.3 Always perceived as an obstacle }(n=3) \\
\text { 2. Positive change in the representation of age (limitation to strength) }(n=13) \\
\text { 3. Negative change in the representation of age }(n=16) \text { : } \\
\text { 3.1. From a strength to a limitation }(n=7) \\
\text { 3.2. From a limitation to an obstacle }(n=7) \\
\text { 3.3. From a strength to an obstacle }(n=2)\end{array}$ \\
\hline & $\begin{array}{l}\text { I. Changes or stability in the } \\
\text { representation of their stage in } \\
\text { their working life }\end{array}$ & $\begin{array}{l}\text { 1. Stability in the representation of their stage in their working life }(n=35) \text { : } \\
\text { 1.1. Stable feeling of being at the mid-point of their career }(n=14) \\
\text { 1.2. Stable feeling of being at the end of their career }(n=21) \\
\text { 2. Changes in the representation of their stage in their working life }(n=26) \text { : } \\
\text { 2.1. From the feeling of being at the midpoint to that of being at the end }(n=23) \\
\text { 2.2 From the feeling of being at the end to that of being at the mid-point }(n=3)\end{array}$ \\
\hline
\end{tabular}

The second main analysis stage consisted in qualitatively reconstructing, in the form of a narrative discussion [116] (pp. 254-255), the different processes of labour market reintegration. To achieve this, the three researchers first began a content analysis of the collected material so as to understand the interconnections between the dimensions, sub-dimensions, and categories of the analysis grid for each participant. An inter-case analysis, that is between the participants, was then conducted [114], which allowed us to bring together processes presenting strong similarities. By grouping together similar cases and by analyzing the interconnections between the dimensions, sub-dimensions, and categories of the analysis grid, a typology composed of three reintegration processes was then constructed. Using a progressive and iterative approach, this typology was gradually improved through exchanges between the three researchers with the analysis triangulation method [116]. Finally, by interpreting and integrating the relations between the sub-dimensions and categories of the analysis grid, each of the three processes was described in detail. Two of the analysts divided up the 61 study cases in order to place them in one of the three identified types of processes. The most difficult cases were arbitrated by a third analyst in the form of blind tests.

\subsubsection{Quantitative Analysis Procedure}

Complementary quantitative data processing was conducted to enhance our understanding of the reintegration process. Using SPSS 24 software, a non-parametric procedure that is an inter-group comparison (i.e., between the three reintegration processes) was conducted on four sub-dimensions of the qualitative analysis grid: F, G, H, and I. So as to avoid too large a dispersion of the participants, these four sub-dimensions were processed dichotomously.

Furthermore, considering the limited number of participants and several convergences between the first two types of processes in the typology developed here, these two processes were combined into a sole category (increasing fragility). We then calculated the frequency distribution resulting from the comparative analysis of the two reintegration processes thus identified and each of the four dichotomous sub-dimensions. Pearson chi-squared tests were used to verify the existence of relations between the processes and sub-dimensions, and odds ratio calculations were used to estimate the size of the possible relations [117].

\section{Results}

We first present the three qualitatively reconstructed integration processes. We then present the results of the complementary statistical analyses.

\subsection{A Blocked Reintegration Process Marked by of Sense of Deadlock}

There were 12 participants in the first process, that is, $20 \%$ of the sample, split equally between men and women. Three quarters of these participants were in the two highest age brackets (51-55 years old, 
$n=4 ; 56$ years and over, $n=5$ ). Half had university degrees, four others had community college diplomas, and the other two had high school diplomas.

All of these participants experienced a "chaotic" reintegration marked by a sporadic presence in the labour market. Three of these participants found no work during the whole length of the study. Most $(n=9)$, however, found at least one job during the process. These jobs were far from meeting their expectations and required compromises that were not very useful, since these participants all found themselves once again unemployed. Some had to accept a string of precarious jobs ( 3 to 5 in 18 months) that paid poorly and had no connection with their skills. This was the case for a former community organization director who had worked in, in the same month, two part-time jobs for which he was over-qualified as an administrative support agent, before finding himself once again unemployed. Others succeeded in finding a fairly steady job that was somewhat associated with their skills, but had to take a sizable drop in advantages (e.g., salary, appeal of the tasks). After a year, however, they lost these jobs that they thought were stable, "a hard blow for my pride, especially at 55". One university graduate in her fifties recounted the following:

"It took me 18 months to find another job. This job wasn't at all what I had done before, not at the hierarchical level, at the responsibilities level, or the salary level. ( . . . ) I also had to make sacrifices: ( . . ) I spent the year driving [between my house and my workplace] ( . . ). I was certain they were going to renew my contract for another two years, but they let me go!"

Eighteen months after T1, all of these workers were still looking for a job, having to endure both occupational downgrading and precariousness. They thus had to deal with severe financial precariousness, especially when they did not have the right to employment insurance. The contrast with their former work situation was even more striking, given that most $(n=10)$ had had a stable, permanent job and half had held management or administrative positions.

Having to constantly deal with "doors that close in your face" and "never-returned phone calls", all of the participants reported having encountered sizable obstacles. Among them, a little more than half $(n=7)$ said they were confronted with obstacles that were both individual (e.g., overly specialized expertise) and contextual (e.g., hiring discrimination because they were perceived to be too costly for employers).

Feeling disheartened because neither their skills nor their experience were acknowledged, almost all these participants $(n=11)$ had a negative occupational self-esteem at FT. They wondered about their place as workers, as stated by this participant:

"You lose your confidence about being able to find a new job but also about your personal worth. (...) It's as if you're worth less because you can't find a job and because you're unemployed even though you're still young enough to work!"

At FT, all the participants expressed uncertainty or resignation about their future in the labour market. Considering that the situation "could not be worse" than the one they were in, they said that they had no other goals than to remain in the job market and meet their needs in the short-, mid-, and even long-term. A university graduate in her early fifties told us that she was ready to accept "just about anything":

"I hit two walls one after the other. It's like having a serious illness; you don't see things the same way anymore. I keep telling myself, "As long as I make enough to get by, it's okay!"

Repeated failure to reintegrate the labour market and the sense of an impasse that accompanied this failure led many of these workers to reconsider their relationship to work. "It's like something has been torn apart," emphasized one female participant. The change was especially noticeable as regards the relative place of work in their lives. In fact, whereas at T1, more than half of them (7/12) saw work as a priority in life, at FT, these people, with only one exception, relegated it to a place that was equal or secondary to the other spheres of activities. This distance they had adopted regarding work was seen as a stop-gap measure, an enforced "letting go," as one woman reported: 
"[Before,] work was the centre of my life. ( ... ) I've had several [difficult] situations [in the last year and a half]. And then I realized that I had lowered my [expectations] concerning work. ( ... ) Now the most important thing is my family life, then [second], my personal life, and, after that, work."

As regards the main purpose of work, most of the participants in this process $(9 / 12)$ maintained the same position during the 18 months of the study (expressive, $n=4$; instrumental, $n=5$ ). The three others went from a view of work as a privileged place where one "fulfils oneself" to a "pay-the-rent" view, in the words of one female administrator. Consequently, the instrumental purpose was in the majority at FT (8/12), whereas the expressive purpose dominated at the beginning of the study $(7 / 12)$.

As concerns the representation of age, half of the participants maintained a negative view from the beginning till the end of the reintegration process. For a third of the participants, however $(4 / 12)$, their representation of age evolved negatively: age became an obstacle to occupational progress at FT, whereas it was seen as a strength at T1. One female participant deplored the fact that employers took advantage of her years of experience without paying her accordingly and treated workers her age like "cheap labour".

As for their representation of what stage they were at in their working life, almost half of the participants $(n=5)$ went from the impression that they were at the midpoint, where it was still possible to develop work projects, to the belief that it was basically over, that the main part of their working life was behind them. As one administrative executive summarized, "All the things I like to do are over. It's too late and I can't do anything about it".

\subsection{A Downgrading Reintegration Process Marked by the Sense of Being Undervalued on the Labour Market}

In this second process, which comprised 20 participants (32\%), women represented close to two-thirds ( $n=13$ ) of the group. Unlike process 1 , most of the workers $(80 \%)$ were concentrated in the two youngest age brackets of the sample: $45-50$ years old $(n=9)$ and $51-55(n=7)$. Their educational level was heterogeneous: the number of participants with a high school diploma $(n=8)$ was similar to those with a university degree $(n=9)$, whereas half this number $(n=4)$ had a community college diploma.

These participants had for the most part held one or two jobs during T1-FT. Of these, half $(n=10)$ were employed for most of the period under study ("winding" path); a slightly smaller number $(n=7)$ experienced more employment/unemployment intermittence ("chaotic" path).

All the workers in this process had a job at FT, but their situations had substantially degraded since T1. Close to two-thirds $(n=13)$ had experienced occupational precariousness, going from a stable job (e.g., permanent, renewable contract) to casual or on-call jobs. Slightly more than half $(n=11)$ were obliged to accept part-time jobs, which led several to hold jobs in heterogeneous activity sectors (e.g., secretarial and restaurant). Moreover, the job held by almost one out of two participants $(n=9)$ at FT was in a quite different activity sector from that held at T1. What is more, a third $(n=7)$ underwent occupational downgrading, quite often going from a technician-level job to a labourer-level job. Finally, close to two thirds $(n=13)$ experienced considerable financial precariousness. (By financial precariousness, we mean a loss of at least $\mathrm{C} \$ 250$ per week (gross income). This represents an annual decrease of some $\$ 13,000$ in a context in which the median employment income for all the Province of Québec was $\$ 35,746$ [118].)

The fact of finding a precarious job for which they were over-qualified was seen by these workers as a consequence of the obstacles they encountered. For instance, they noted the importance of individual obstacles $(n=7)$ related to their training (e.g., lack of certification) or to health problems. Others $(n=7)$ mentioned that the individual obstacles were added to contextual obstacles, especially ageism. One woman summarized it thus, "Yes, they acknowledge my skills but they always say that I'm missing something for the job".

The majority of the participants in this process $(n=15)$ expressed, like those in process 1 , a negative occupational self-esteem at FT. Even though they were employed, they felt underappreciated as 
workers and unacknowledged by employers. They felt that they "could have been put to better use" in the words of one female participant. In this situation, most of them were looking, more or less actively, for another job with more "decent" conditions, given the stage they were at in their working life (e.g., regular, daytime work hours) and their skills. This was the case for a manager in his fifties whose new job at FT was fairly stable (renewable contract) but whose tasks were those of a subordinate.

As for their future in the labour market, most of them expressed serious doubts about any real possibilities of improving their situation.

As concerns the relative importance of work, it decreased for half of these participants $(n=10)$ over the 18 months. Most often at T1, work was on an equal footing with the other spheres of life but in a secondary position at FT. It also went from a primary importance to an equal or secondary importance with respect to the other spheres in life. Moreover, close to half the workers belonging to this process $(n=9)$ readjusted what they considered to be the main purpose of work, this occurring on a much larger scale than in the other processes. Seen as an end unto itself and a source of "accomplishment" (expressive purpose) at T1, work by FT became a way of ensuring one's subsistence and financial independence (instrumental purpose). As expressed by a former manager who reconverted, "for lack of anything better to do," into a carpenter, work lost its meaning and was nothing more than a "necessary evil [because] you have to work in life".

What is more, with little hope of finding a job in keeping with their occupational skills, almost half of the participants $(9 / 20)$ stated there was a negative evolution in their representation of age during the 18 month period. Some who, at T1, saw it as a factor in renouncing new work projects (limitations), saw it at FT as an outright obstacle to their occupational progress. The others, who initially saw their age as a strong point in their labour market reintegration, at the end saw it as a limitation or even an obstacle.

Likewise, slightly more than a third of the participants $(n=7)$ felt they were at the end of their working lives at FT, whereas they were confident they were at the midpoint of their working lives at T1. This was expressed by a former sales representative in his mid 50s, humiliated and obliged to make a living as a janitor:

"I think my working life is behind me now. ( ... ) Before, I had a much better position: I was a lot more than a janitor! I would have liked to finish out my working life doing something other than cleaning buildings."

\subsection{A Sustainable Reintegration Process Marked by a Sense of Enhanced Integration in the Labour Market}

This third process grouped together 29 participants, that is, close to half (48\%) the sample. As in the second process, women were in the majority $(n=20 ; 69 \%)$. More than $85 \%$ were concentrated in the youngest age brackets: close to one out of two $(n=14)$ were from 51 to 55 years old, and a little more than a third $(n=11)$ were from 45 to 50 . Most had a high school $(n=12 ; 41 \%)$ or community college $(n=10 ; 35 \%)$ diploma.

The reintegration paths these people experienced were either "linear" $(n=20)$ or, more rarely, "winding" $(n=9)$, with little or no intermittence between jobs. In the case of the linear paths, most of the participants joined organizations early on in which they were still working at FT. The winding path involved people who chose occupational retraining at $\mathrm{T} 1$.

At the end of the 18-month-long study, the majority of the participants in the third process had found a job in-keeping with their aspirations and of the same qualification level as the job that they had lost. Almost all $(n=27)$ found themselves in stable jobs of the same status as at T1 (i.e., permanent or contractual). Most of the participants $(n=23)$ did not experience financial precariousness and earned a salary at FT comparable to that of T1.

While the return to a stable job was not without its difficulties, most of these workers $(n=22)$ considered that they had not encountered major difficulties since, in the end, they had "found their place". 
In this context, all of them considered their occupational self-esteem to be positive at FT: their self-confidence as workers was reinforced by the fact that they had found jobs that provided them with acceptable working conditions and long-term integration into the job market.

What is more, three quarters of these workers $(n=22)$ saw their future working life optimistically and said they were confident that they would keep their job for several more years. This job was often seen as a "good job to finish your career with" in the words of one educational consultant in her early fifties. As for a few other participants $(n=7)$, they accepted, fairly serenely, to finish their working lives with the job they had found, even though it did not exactly correspond to what they would have preferred. This was the case for a woman in her mid-forties, with a community college teaching diploma, who found a job in her field, but only for $28 \mathrm{~h}$ a week:

"Of course I would have liked to work closer to home and to have a few more hours per week $(\ldots)$. But the way it is, if nothing changes [and there are no more job offers in the next few years], I can see myself where I am now, and that's okay."

Unlike the other two processes, most of these participants $(n=22)$ attributed the same relative importance to work all throughout their reintegration path, which in general was equal to the importance of other spheres in their life. As one woman explained, "Work has never been and never will be the priority in my life, but it's still up there with my family and health". Moreover, in the few cases where the relative importance of work decreased $(n=6)$, this activity remained a sphere of significant investment at FT (of a primary to equal importance).

As concerns the dominant purpose attributed to work, slightly more than one participant out of two $(n=16)$ maintained their perception of work as a source of "accomplishment", a "pleasure", or a "service" rendered to society (expressive purpose) all throughout the T1-FT period. The attribution to work of more instrumental values was a rare phenomenon (4/29).

Regarding their representation of age, close to one participant in three $(n=10)$ continued all throughout their reintegration path to associate age with occupational "challenges" that were still within reach (strength). One man described it as follows:

“Being over 50 is not a reason to say, 'You can't find another job.' On the contrary, there are always jobs available whatever your age. You've got experience. You'll always manage to find something."

Moreover, a comparable proportion $(n=9)$ developed a more positive view of their age (from a limitation to a strength) between T1 and FT, which was reinforced by the feeling of having successfully returned to the labour market, sometimes above and beyond their hopes.

As for their representation of the stage in their working life, it remained the same from T1 to FT for more than half of the participants (17/29). Either they already saw themselves as being at the end of their working life at T1 $(n=11)$, or, to a lesser extent, they continued to see themselves as being at the midpoint. The others $(n=12)$ went from a feeling of being at the midpoint (T1) to that of being at the end of their career (FT). The latter reported being satisfied with their repositioning in the labour market and with their accomplishments in their working life, as well as being happy to undertake the last leg of their working life.

\subsection{Complementary Statistical Analyses}

Regarding objective 2, a moderate statistically significant relation was observed between the types of reintegration process and changes in three of the four sub-dimensions from T1 to FT (Table 2): the relative importance of work with respect to the other spheres of life $\left(\chi^{2}{ }_{(1)}=6.814, p<0.01\right)$, the dominant purpose of work $\left(\chi^{2}(1)=4.419, p<0.05\right)$, and the representation of one's age in the labour market $\left(\chi_{(1)}^{2}=5.696, p<0.05\right)$. However, these latter results should be interpreted cautiously because of their moderate level of significance. 
Table 2. Change or stability in the relative importance of (1) work with respect to the other spheres in life, (2) the dominant purpose of work, (3) the representation of age in the labour market, and (4) the representation of the stage in one's working life according to the type of reintegration process.

\begin{tabular}{|c|c|c|c|}
\hline Type of Reintegration Process Evolving Variables & $\begin{array}{l}\text { Increasing Fragility } \\
\quad n=32(100 \%)\end{array}$ & $\begin{array}{c}\text { Sustainable Integration } \\
\quad n=29(100 \%)\end{array}$ & Chi Squared \\
\hline \multicolumn{4}{|l|}{ Change in the relative importance of work $\left.{ }^{* *}\right)$} \\
\hline Decrease in the relative importance & $17(53.1)$ & $6(20.7)$ & \\
\hline Stability in the relative importance & $15(46.9)$ & $23(79.3)$ & $6.814(* *)$ \\
\hline \multicolumn{4}{|l|}{ Change in the dominant purpose attributed to work $\left({ }^{*}\right)$} \\
\hline Change from expressive to instrumental purpose & $12(37.5)$ & $4(13.8)$ & \\
\hline Stability in the dominant purpose & $20(62.5)$ & $25(86.2)$ & $4.419\left(^{*}\right)$ \\
\hline \multicolumn{4}{|l|}{ Change in the representation of age in the labour market $\left(^{*}\right)^{(b)}$} \\
\hline Negative change in the representation of age & $13(40.6)$ & $3(12.0)$ & \\
\hline Stability or positive change in the representation of age & $19(59.4)$ & $22(88.0)$ & $5.696\left(^{*}\right)$ \\
\hline Change in the representation of the stage in one's working life (n.s.) & & & \\
\hline Feeling of being at the mid-point of one's career compared to that of being at the end & $12(37.5)$ & $11(37.9)$ & \\
\hline Stability in the representation of the stage in one's career ${ }^{(c)}$ & $20(62.5)$ & $18(62.1)$ & 0.001 (n.s.) \\
\hline
\end{tabular}

n.s.: not statistically significant; ${ }^{*} \mathrm{p}<0.05 ;{ }^{* *}: p<0.01$. $^{(\mathrm{a})}$ including the rare participants $(n=4)$ whose dominant purpose went from instrumental to expressive between T1 and FT (b) four participants were excluded because their responses could not be coded; (c) including the rare participants $(n=3)$ whose feeling went from being at the end to the mid-point of their career between $\mathrm{T} 1$ and FT. 
The odds ratio method [117] indicates that, among the workers who experienced increasing labour market fragility as compared to those whose reintegration was sustainable, the probability over the 18-month period of stepping back from work with respect to the other spheres of life was 4.3 times greater; that of instrumentalizing work, that is, making it a means to an end, 3.8 times greater; and that of developing a negative perception of one's age in the labour market, 5 times greater.

On the other hand, the change in one's feeling that one is at the midpoint of one's working life to that of being at the end of it did not appear to be significantly related to the type of reintegration process $\left(\chi_{(1)}^{2}=0.001\right.$, n.s.). It is worth noting that none of the four variables examined appeared to be significantly related to the participants' chronological age.

\section{Discussion}

The results of the study presented here shed light, on the basis of statements from interviews with unemployed workers 45 years old and over, on three labour market reintegration processes. They also suggest some moderate statistical relationships between these processes and three variables associated with the relationship to work and the workers' identities.

\subsection{Key Findings}

\subsubsection{Occupational Repositioning in the Labour Market: Contrasting Experiences}

Echoing previous research that emphasizes the difficulties that older unemployed workers have in Canada and in Québec in their attempts to re-enter the job market (e.g., [24,25,30]), our results showed that, after 18 months of study, less than half of the workers that we met had found a stable job in keeping with their accumulated experience and qualifications (process 3). Conversely, the other half of the participants were still without work (process 1) or confronted with financial and occupational precariousness, downgrading, and underemployment (processus 2), a reality which numerous authors have observed (e.g., [26,27,29,66,71,119]). Moreover, examining, from a diachronic perspective, the reintegration of unemployed older workers as a psychosocial transitional process $[94,95,97]$, our study adds to existing knowledge by relating the sequence of major events in the three reintegration processes identified here with the way the workers experienced and gave meaning to them. The three types of processes accordingly describe contrasting experiences that can be located on a continuum.

At the one end of this continuum, process 1 brought together people who were unemployed following a sequence of entries into and exits out of the labour market, without any real control of the key events on their path. The reintegration path was thus seen as a genuine "failure" which, in addition to the financial losses, was seen as an "irreversible" rupture that was above all unexpected in their career path and that led them to doubt themselves and their ability to turn the situation around. At the other end, the workers in process 3 repositioned themselves in jobs that were comparable to those they had lost, and this after a fairly short time without any significant obstacles. The experience was interpreted here as an "incident" in their career path which, far from being perceived negatively, contributed rather to strengthening their self-esteem as workers and their confidence in their future career path. Between these two ends of the spectrum, the participants comprising process 2 had jobs, but their reintegration path was marked by numerous obstacles and periods of unemployment. The reintegration process was perceived as a genuine "downgrading" given the considerable financial losses they encountered and their decline in job status. The participants said the experience was like sliding down a slippery slope, a downward career path over which they had little or no control. More fundamentally, it was interpreted as an attack on their dignity and the loss of their place in the labour market.

These results illustrate the notion according to which re-entering the labour market after losing a job at 45 or older constituted, for the interviewed workers, a pivotal moment in the stages in their life $[93,94]$. They also show the importance of taking into account, so as to grasp its complexity, 
how workers experienced this reintegration process over time and gave it meaning. The results demonstrate, moreover, that this process created a strong destabilization in the participants' identity and a feeling of discontinuity, and even a rupture in their career path in processes 1 and 2. Conversely, for the participants in process 3 , their reintegration would seem to have contributed to a strengthening of their occupational and social identity and their sustainability in the labour market.

\subsubsection{The Two Faces of Occupational Repositioning}

As concerns occupational repositioning, it is clear that there are some nuances to be made at an objective level about the distinction between a return to work versus recurrent unemployment, particularly with regard to the workers' subjective experience. Indeed, while only 12 of the participants $(19 \%)$ were unemployed at the end of the study (process 1), a large proportion of those who returned to the labour market ( $40 \%$, process 2 ) were faced with precarious employment that was particularly difficult to handle. Hurt not only at the occupational and financial level but also at the psychosocial level, these older workers expressed, like those who were unemployed, a psychological malaise and a feeling of a "loss of self" [11,89], a social uselessness [92]. These results are worthy of researchers' and practitioners' attention given that a greater number of workers now navigate in career paths marked by precarious employment and come with more complex guidance needs $[4-9,90,105,120]$. These results contribute at the same time to enhancing our comprehension of the deleterious consequences, for workers 45 and over, of not being able to reposition themselves in the labour market. That is to say, to meet not only minimal standards in terms of working conditions (e.g., safety, social advantages) but also to satisfy their aspirations for a decent job and a career that promotes effective and sustainable well-being (e.g., [2,3,37-39,41-44]).

\subsubsection{Relationship to Work and the Reintegration Process: A Complex Interaction}

Given the links between the reintegration experience and the relationship to work, our results accordingly indicated that a third of the participants reported a decrease in the relative importance they accorded to work. The statistical analyses showed that this decrease involved more destabilized workers (processes 1 and 2), who were experiencing the most difficult reintegration situations. This result enhances our understanding of the variability of the relative value attributed to work based on recent experiences in this activity sphere (e.g., [46,56,57]). Additionally, while the greater distance that participants put between themselves and work can be interpreted as a strategy to preserve their occupational identity, particularly their self-esteem (e.g., [60,61]), our analyses also showed that this "choice" was often reported by those whose self-esteem had declined the most at FT. This result suggests that greater nuance is required to interpret the distance that workers put between themselves and work, at least in terms of its effectiveness in protecting themselves. Indeed, this distance could also illustrate how the decrease in the importance accorded to work contributes to a lowering of one's own self-esteem rather than protecting it, thereby confirming the observations of several authors, particularly in cases where people had previously accorded a great deal of importance to their work $[66,68]$.

With respect to the relations between repositioning oneself in the labour market and changes in the dominant purpose of work, our analyses suggested that more than one third of the participants in processes 1 and 2 went from an expressive purpose to an instrumental one (vs. only $14 \%$ in process 3 ). However, the qualitative analysis reveals that this transition was associated more with individuals in process 2, those whose occupational repositioning led to a downgrading professional path. Thus, a possible hypothesis could be that the instrumentalization of work translates a work's loss of meaning more than a deliberate strategy allowing the study's participants in process $2[34,63]$ to deal with the difficulties of reintegration. Although this result has to be interpreted cautiously and needs to be confirmed with a larger sample and with different populations of workers, it deserves the attention of researchers and practitioners given that remaining in a work situation that "makes no sense" can have considerable impact on the psychological health of workers $[27,66,82]$, but also because the participants in process 
2 belonged to the youngest age category and will have to stay in the job market for several more years. From a psychology of sustainability perspective, this result stresses the necessity of acting to promote meaningfulness in organizations using a primary prevention intervention approach [3].

\subsubsection{Representations of Oneself as a Worker and the Reintegration Process: Mixed Interactions}

Our statistical results revealed that the negative evolution of the representation of age was more often a problem for the destabilized workers in processes 1 and 2, as was the relationship to work. This result leads us to suggest the hypothesis of a significant long-term relationship between, on the one hand, downgrading and the loss of social status and, on the other, the destabilization of the occupational and social identity of the participants in our study. The comments of the workers in processes 1 and 2 gave particularly evocative illustrations of the difficulties involved in both returning to the labour market with a job in keeping with one's skills and in composing with the status of an "unemployed older worker", that is, someone who is "difficult to employ". These two elements contributed to both a feeling of loss and identity deconstruction $[64,83,84,88]$. Conversely, the positive evolution in the representation of age primarily concerned workers whose attachment to their work was reinforced (process 3). Even if this result cannot be generalized and requires to be validated with more data, it seems to support the idea according to which, when people find jobs during their reintegration that have meaning for them and in which they feel acknowledged, their occupational and social identities are not only likely to be preserved but also to be reinforced $[72,76,80,121]$.

As for their representation of the stage they were at in their working life and the change in the representation according to the process, our results did not reveal any statistically significant difference. However, the qualitative analysis of their statements helps us to better understand how the transition from a feeling of being at the midpoint in one's working life (T1) to that of being at the end (FT) can represent two quite distinct realities. On the one hand, people who experienced a stronger attachment to their jobs (process 3) seemed to correspond to the definition that Marbot [62] gave to the feeling of being at the end of one's working life, that is, a serene acceptation of a new stage in one's life at work and a corresponding redefinition of one's priorities in life. Generally proud of what they have accomplished in their working lives, the participants said that they simply wished to "hold onto what they had gained" and chose to adjust their expectations and life goals accordingly.

That being said, our analysis of the destabilized participants' statements (processes 1 and 2) illustrated a whole other reality. Moving from a feeling of being at the midpoint of their working life to that of being at the end appeared to be the consequence of an identity impasse. This impasse was provoked by the gap between the representation that the participants had of themselves and what they had to offer at T1, and that which society was sending back to them over the 18 months. Our data illustrates the tension between a social identity for oneself and for others, as well as the destabilization that this tension can lead to when the gap between these two dimensions of social identity becomes too large $[34,79,87]$. Moreover, taking into account the medium-term effects of the reintegration on the workers' identity, these results add to the scientific assessment of the way in which unemployment and occupational downgrading can generate a feeling of social uselessness in seniors and even marginalization (e.g., [11,91,92]).

\subsection{Limitations}

Our study has several limitations. First, because our sample includes a relatively small number of workers, the interpretation of our results must be done with a lot of caution. In addition, although the sample is quite diverse (for example, in education), it is not statistically representative of the population of the unemployed aged in Quebec City, the province of Quebec, or Canada. Thus, it is difficult, if not impossible, to generalize our results to all Canadian workers.

Besides, we did not take into account the context of the Canadian labour market. It would probably have been interesting to do so but this would have wildly overpassed the goals of the present study. 
Finally, the present study has operationalized the relation to work and the representations of identity using a limited number of variables, whereas these notions are multidimensional and complex as mentioned in the literature (for example, [47,49]).

\subsection{Implications for Research}

The present study could be extended at various levels. First, a larger sample would allow us to verify the validity of the three reintegration processes identified here and to confirm the statistical relations observed between the types of processes and the change in the psychosocial variables studied. It would also enable us to shed light on the role of socio-biographic variables (e.g., age, education) in the statistical relations observed. Specifically, it would be worthwhile to compare workers aged 45-60 versus those aged 60 and over so as to better understand the effect of aging in the labour-market reintegration process and the way it is experienced. Likewise, a more diversified sample in terms of age would have allowed us to determine whether the statistical relationships observed also concerned younger unemployed workers.

Second, it would be appropriate to pay particular attention to the multidimensionality of the notion of relationship to work and of identity representations in future research. Concerning the relationship to work, it would be worthwhile to have regard the absolute value of work [122,123], as well as the representation of a decent job and a sustainable work life from the participants' perspective $[3,19,38]$. Concerning identity, aside from a more precise operationalization of occupational and social identities, it would be interesting to compare the changes in the representations of oneself as a worker with changes in the self-representations in other spheres of life. Indeed, given the interdependence of life roles, occupational changes are likely to have an impact on work life but also on life outside work, in particular on one's personal and family life [100].

Third, it would be relevant to study the labour market reintegration processes over a longer period than the 18-month period of the study in order to take into account their sustainability from a psychological perspective, as well as to analyze to what extent the scarring psychosocial effects of job loss at this stage of life might last.

\section{Conclusions}

Our results suggest some reflections concerning organizational policies for the management of older workers. The latter would benefit from taking into account the particular needs of these workers, especially the expectations they pursue in their working lives according to the stage of their lives (e.g., mid-career or end of career). They could also pay particular attention to the wealth of skills that many can offer to support the sustainable development of the organization. In short, older worker management policies that would support a better linkage between the particular needs of these workers and those of the organization are likely to generate greater individual well-being at work and, in turn, to contribute to the sustainable development of organizations.

Our results also suggest some reflections regarding individual counseling with workers aged 45 and over in their search to reintegrate the labour market. It would be helpful to help people develop their personal and professional enrichment strategies (e.g., [3,37,38,40,41,124]). It would likewise seem important to develop interventions that take into account the priorities and living context of unemployed older workers, what they expect regarding work, and how they conceive their future in the labour market. Moreover, practitioners should be attentive to the nature of the identity wound in question, the meaning accorded to it, and the strategies to be developed to limit its long-term impact. In order to re-contextualize this meaning, they could pay particular attention to the circumstances surrounding the loss of employment and to what that meant for the workers. Finally, it could be highly relevant to use an intervention based on a narrative approach [8,125-128], as promoted by the «meaning paradigm» [3]. With such an approach, the accompanied people are invited to think about the meaning of their past experiences in order to choose what they want for the 
future. Through their stories, it is also possible to identify key elements at both the individual and organizational levels that may promote sustainable development and well-being.

Author Contributions: G.F. and H.Z. wrote the paper jointly. G.F. is the scientific director of the research project on which the present article is based. She is the recipient of the research funding allowed to the project, and she managed all its steps from its design to the investigation and data analysis. J.M., a specialist of psychosocial transitions, contributed to the writing of the article by commenting, in detail, on a draft version of the whole article. C.G. participated in the empirical investigation and conducted the analysis of the data collected, along with G.F. and H.Z.

Funding: This research was funded by Social Sciences and Humanities Research Council of Canada grant number [CH086689].

Conflicts of Interest: The authors declare no conflict of interest. The founding sponsors had no role in the design of the study; in the collection, analyses, or interpretation of data; in the writing of the manuscript; or in the decision to publish the results.

\section{References}

1. Krahn, H.; Graham, S.L.; Hughes, K.D. Work, Industry and Canadian Society, 7th ed.; Thomson Nelson: Scarborough, ON, Canada, 2014; ISBN 0176531939.

2. Di Fabio, A. Positive Healthy Organizations: Promoting well-being, meaningfulness, and sustainability in organizations. Front. Psychol. 2017, 8, 1938. [CrossRef] [PubMed]

3. Di Fabio, A. The psychology of sustainability and sustainable development for well-being in organizations. Front. Psychol. 2017, 8, 1534. [CrossRef] [PubMed]

4. Kalleberg, A.L. Precarious work, insecure workers: Employment relations in transition. Am. Sociol. Rev. 2009, 74, 1-22. [CrossRef]

5. Vosko, L.F. (Ed.) Precarious Employment. Understanding Labour Market Insecurity in Canada; McGill University Press: Montreal, QC, Canada, 2006; ISBN 0773529624.

6. Gash, V. Bridge or trap? Temporary workers' transitions to unemployment and to the standard employment contract. Eur. Sociol. Rev. 2008, 24, 651-668. [CrossRef]

7. Mette, C. En Quoi les Conditions de Travail Sont-Elles Liées au Parcours Professionnel Antérieur? DARES Analyses, 2018. Available online: http:/ / dares.travail-emploi.gouv.fr/IMG/pdf/2018-002v2.pdf (accessed on 17 May 2018).

8. Savickas, M.L.; Nota, L.; Rossier, J.; Dauwalder, J.-P.; Duarte, M.E.; Guichard, J.; Soresi, S.; Van Esbroeck, R.; van Vianen, A.E.M. Life designing: A paradigm for career construction in the 21st century. J. Vocat. Behav. 2009, 75, 239-250. [CrossRef]

9. Valenduc, G.; Vendramin, P.; Pedaci, M.; Piersanti, M. Changing Careers and Trajectories. How Individuals Cope with Organisational Change and Restructuring (Works Project); Université Catholique, Higher Institute of Labour Studies: Louvain, Belgium, 2009; Available online: http:/ / www.ftu-namur.org/fichiers/WORKSChanging_careers_and_trajectories.pdf (accessed on 17 May 2018).

10. Brouwer, S.; Bakker, R.H.; Shellekens, J.M.H. Predictors for re-employment success in newly unemployed: A prospective cohort study. J. Vocat. Behav. 2015, 89, 32-38. [CrossRef]

11. Klehe, U.-C.; De Pater, I.E.; Koen, J.; Kira, M. Too old to tango? Job loss and job search among older workers. In The Oxford Handbook of Job Loss and Job Search; Klehe, U.-C., van Hooft, E.A.J., Eds.; Oxford University Press: Oxford, UK, 2017. [CrossRef]

12. National Seniors Council. Older Workers at Risk of Withdrawing from the Labour Force or Becoming Unemployed: Employers' Views on How to Retain and Attract older Workers; Gouvernement du Canada: Ottawa, ON, Canada, 2013; Available online: https://www.canada.ca/en/national-seniors-council/programs/publicationsreports/2013/older-workers-risk.html (accessed on 17 May 2018).

13. Fournier, G.; Zimmermann, H.; Gauthier, C. Instable career paths among workers 45 and over: Insight gained from long-term career trajectories. J. Aging Stud. 2011, 25, 316-327. [CrossRef]

14. European Commission. Facts and Figures: Healthy Workplaces Campaign for All Ages 2016-2017. Fact Sheet, 2016. Available online: http://europa.eu/rapid/press-release_MEMO-16-1421_en.htm (accessed on 16 May 2018). 
15. Fields, A.; Uppal, S.; LaRochelle-Côté, S. The Impact of Aging on Labour Participation Rates. In Insights on Canadian Society; Juin; Statistics Canada: Ottawa, ON, Canada, 2017; Available online: http:/ / www.statcan. gc.ca/pub/75-006-x/2017001/article/14826-eng.htm (accessed on 16 May 2018).

16. U.S. Bureau of Labor Statistics. Share of Labor Force Projected to Rise for People Age 55 and over and Fall for Younger Age Groups. Available online: http:/ / www.bls.gov/opub/ted/2014/ted_20140124.htm (accessed on 16 May 2018).

17. Di Fabio, A. Constructing and Managing Personal Project, Career Project, Life Project: The Challenge of Sustainability; Invited Lecture; Faculty of Health Sciences, Hokkaido University: Sapporo, Japan, 30 July 2016.

18. Di Fabio, A.; Kenny, M.E. The contributions of emotional intelligence and social support for adaptive career progress among Italian youth. J. Career Dev. 2015, 42, 48-59. [CrossRef]

19. Di Fabio, A.; Kenny, M.E. From decent work to decent lives: Positive Self and Relational Management (PS\&RM) in the twenty-first century. Front. Psychol. 2016, 7, 361. [CrossRef] [PubMed]

20. Kenny, M.E.; Hage, S.M. The next frontier: Prevention as an instrument of social justice. J. Prim. Prev. 2009, 30, 1-10. [CrossRef] [PubMed]

21. Burke, T. L'âge et le Droit du Travail au Québec: Vers un Milieu de Travail Égalitaire et Pluriactif Pour les Personnes Salariées de Tous Âges. Ph.D. Thesis, Laval University, Quebec, QC, Canada, 2014. Available online: http://www.crimt.org/PDF_Theses_Memoires/Burke_Tanaquil_2013_these.pdf (accessed on 18 May 2018).

22. Government of Canada. Canadian Centre for Occupational Health and Safety Aging Workers. Fact Sheets: Aging Workers. Available online: http://www.cchst.ca/oshanswers/psychosocial/aging_workers.html (accessed on 17 May 2018).

23. OECD. Back to Work: Re-Employment, Earnings and Skill Use after Job Displacement. In OECD Employment Outlook 2013; OECD Publishing: Paris, France, 2013; pp. 191-231, ISBN 9789264201293. Available online: https://read.oecd-ilibrary.org/employment/oecd-employment-outlook-2013_empl_ outlook-2013-en\#page1 (accessed on 17 May 2018).

24. Statistics Canada. Labour Force Survey Estimates (LFS), by Sex and Detailed Age Group Annual (Table 282-0002). Available online: http://www5.statcan.gc.ca/cansim/a26?lang=eng\&id=2820002\& retrLang=eng (accessed on 17 May 2018).

25. ISQ (Institut de la Statistique du Québec). Chômage, Durée du Chômage, Activités Antérieures des Chercheurs D'emploi et Taux de Chômage. In Annuaire Québécois des Statistiques du Travail: Portrait des Principaux Indicateurs du Marché et des Conditions de Travail, 2006-2016; Gouvernement du Québec: Québec, QC, Canada, 2017; Volume 13, pp. 109-123. Available online: http://www.stat.gouv.qc.ca/statistiques / travail-remuneration/annuaire-v13.pdf (accessed on 17 May 2018).

26. Lippmann, S. Rethinking risk in the new economy: Age and cohort effects on unemployment and re-employment. Hum. Relat. 2008, 61, 1259-1292. [CrossRef]

27. Bayaz-Ozturk, G.; Gallo, W.T. Effect of Job Loss on Wealth Accumulation of Older Workers, Report for the U.S. Department of Labor, Office of the Assistant Secretary for Policy, Chief Evaluation Office, Evaluation Studies, 2013. Available online: https://www.dol.gov/asp/evaluation/completed-studies/Wealth_Effects_ of_Job_Loss_on_Older_Workers /FINAL_REPORT_wealth_effects_job_loss_older_workers.pdf (accessed on 15 May 2018).

28. Couch, K.A.; Jolly, N.A.; Placzek, D.W. Earning Losses of Older Displaced Workers. A Detailed Analysis with Administrative Data. Res. Aging 2009, 31, 17-40. [CrossRef]

29. Finnie, R.; Gray, D. Labour-Force Participation of Older Displaced Workers in Canada: Should I Stay or Should I Go? IRPP Study 15; Institute for Research on Public Policy: Montreal, QC, Canada, 2017; Available online: http:/ /irpp.org/wp-content/uploads/assets/research/competitiveness/new-researcharticle-2/IRPP-Study-no15.pdf (accessed on 15 May 2018).

30. OCDE. Back to Work: Canada. Improving the Re-Employment Prospects of Displaced Workers; OECD Publishing: Paris, France, 2015.

31. Vansteenkiste, S.; Deschacht, N.; Sels, L. Why are unemployed aged fifty and over less likely to find a job? A decomposition analysis. J. Vocat. Behav. 2015, 90, 55-65. [CrossRef]

32. Wanberg, C.R.; Kanfer, R.; Harmann, D.J.; Zhang, Z. Age and reemployment success after job loss: An integrative model and meta-analysis. Psychol. Bull. 2016, 142, 400-426. [CrossRef] [PubMed] 
33. Bowman, D.; McGann, M.; Kimberley, H.; Biggs, S. 'Rusty, invisible and threatening': Ageing, capital and employability. Work Employ. Soc. 2017, 31, 465-482. [CrossRef]

34. Guillemard, A.-M. Les seniors sur le marché du travail. In Les Défis du Vieillissement; Guillemard, A.-M., Ed.; Armand Colin: Paris, France, 2010; pp. 38-100, ISBN 9782200249205.

35. Macdonald, J.J.; Levy, S.B. Ageism in the workplace: The role of psychosocial factors in predicting job satisfaction, commitment and engagement. J. Soc. Issues 2016, 72, 169-190. [CrossRef]

36. Harris, K.; Krygsman, S.; Waschenko, J.; Laliberte Rudman, D. Ageism and older worker: A scoping overview. Gerontologist 2018, 58, 1-14. [CrossRef]

37. Blustein, D.L.; Olle, C.; Connors-Kellgren, A.; Diamonti, A.J. Decent work: A psychological perspective. Front. Psychol. 2016, 7, 407. [CrossRef] [PubMed]

38. Blustein, D.L.; Kenny, M.E.; Di Fabio, A.; Guichard, J. Expanding the Impact of the Psychology of Working: Engaging Psychology in the Struggle for. J. Career Assess. 2018. [CrossRef]

39. Burchell, B.; Sehnbruch, K.; Piasna, A.; Agloni, N. The quality of employment and decent work: Definitions, methodologies, and ongoing debates. Camb. J. Econ. 2014, 38, 459-477. [CrossRef]

40. Di Fabio, A.; Maree, J.G. Using a transdisciplinary interpretive lens to broaden reflections on alleviating poverty and promoting decent work. Front. Psychol. 2016, 7, 503. [CrossRef] [PubMed]

41. Di Ruggiero, E.; Cohen, J.E.; Cole, D.C.; Forman, L. Public health agenda setting in a global context: The international labor organization's decent work agenda. Am. J. Public Health 2015, 105, 58-61. [CrossRef] [PubMed]

42. ILO (International Labour Organisation). Report of the Director-General: Decent work, International Labour Conference, 87th Session; ILO: Geneva, Switzerland, 1999; ISBN 92-2-110804-X. Available online: http:/ /www. ilo.org/public/english/standards/relm/ilc/ilc87/rep-i.htm (accessed on 17 May 2018).

43. ILO (International Labour Organisation). Decent Work and the Transition to Formalization: Recent Trends, Policy Debates and Good Practices; ILO: Geneva, Switzerland, 2015; Available online: http://www.ilo.org/ wcmsp5/groups/public/ed_emp/emp_policy/documents/meetingdocument/wcms_125519.pdf (accessed on 15 May 2018).

44. Ribeiro, M.A.; Silva, F.F.; Figueiredo, P.M. Discussing the notion of decent work: Senses of working for a group of Brazilian workers without college education. Front. Psychol. 2016, 7, 207. [CrossRef] [PubMed]

45. Fournier, G.; Lachance, L.; Viviers, S.; Goyer, L.; Lahrizi, I.; Masdonati, J. Development of a Multidimensional Questionnaire on the Relationship to Work: An Exploratory Study. Unpublished work.

46. Masdonati, J.; Fournier, G.; Pinault, M.; Lahrizi, I.Z. The evolution of work values during the school-to-work transition: The case of young adults in the "missing middle". Int. J. Educ. Vocat. Guid. 2016, 16, 189-212. [CrossRef]

47. Mercure, D.; Vultur, M. La Signification du Travail: Nouveau Modèle Productif et Ethos du Travail au Québec; Presses de l’Université Laval: Québec, QC, Canada, 2010; ISBN 978-2-7637-9091-6.

48. Morin, E. Donner un Sens au Travail. 2006. Available online: http:/ / docplayer.fr/docview/40/21773181/ \#file=/ storage/40/21773181/21773181.pdf (accessed on 17 May 2018).

49. MOW-International Research Team. The Meaning of Work; Academic Press: London, UK, 1987; ISBN 9780125093606.

50. Rosso, B.D.; Dekas, K.H.; Wrzesniewski, A. On the meaning of work: A theoretical integration and review. Res. Organ. Behav. 2010, 30, 91-127. [CrossRef]

51. Sverko, B.; Babarovic, T.; Sverko, I. Assessment of values and role salience. In International Handbook of Career Guidance; Athanasou, J.A., Van Esbroeck, R., Eds.; Springer: Dordrecht, The Netherlands, 2008; pp. 539-563, ISBN 978-1-4020-6230-8.

52. Sverko, B.; Vizek-Vidovic, V. Studies of the meaning of work: Approaches, model, and some of the findings. In Life roles, Values and Careers; Super, D.E., Sverko, B., Eds.; Jossey-Brass: San Francisco, CA, USA, 1995; pp. 3-21, ISBN 978-0787901004.

53. Méda, D.; Vendramin, P. Réinventer le Travail; Presses universitaires de France: Paris, France, 2013; ISBN 978-2-13-058469-8.

54. Ros, M.; Schwartz, R.H.; Surkiss, S. Basic individual values, work values, and the meaning of work. Appl. Psychol. Int. Rev. 1999, 48, 49-71. [CrossRef]

55. Blustein, D.L. A relational theory of working. J. Vocat. Behav. 2011, 79, 1-17. [CrossRef] 
56. Bujold, C.; Fournier, G.; Lachance, L. The Meaning of Work among Nonstandard Workers: A Multifaceted Reality. Can. J. Couns. Psychother./Revue Canadienne de Counseling et de Psychothérapie 2013, 47, 480-499. Available online: http://cjc-rcc.ucalgary.ca/cjc/index.php/rcc/article/view/2631/2504 (accessed on 17 May 2018).

57. Côté, N. Pour une compréhension dynamique du rapport au travail: La valeur heuristique de la perspective des parcours de vie. Sociol. Soc. 2013, 45, 179-201. [CrossRef]

58. Guichard, J. Identifications, personnalisation et construction de soi. In Penser la Socialisation en Psychologie: Actualité de L'œuvre de Philippe Malrieu; Baubion-Broye, A., Dupuy, R., Prêteur, Y., Eds.; ERES: Toulouse, France, 2013; pp. 205-219, ISBN 2749236428.

59. Vendramin, P. Le sens du travail face aux mutations de l'organisation. Perspective européenne. In Les Risques du Travail: Pour ne Pas perdre sa vie à la Gagner; Thébaud-Mony, A., Davezies, P., Vogel, L., Volkoff, S., Eds.; La Découverte: Paris, France, 2015; pp. 256-264, ISBN 9782707178404.

60. Lagacé, M.; Tougas, F. Les répercussions de la privation relative personnelle sur l'estime de soi: Une étude du rôle du désengagement psychologique auprès de travailleurs de la santé de plus de 45 ans. Les Cahiers Internationaux de Psychologie Sociale 2006, 69, 59-69. [CrossRef]

61. Lagacé, M.; Tougas, F.; Laplante, J.; Neveu, J. Communication Âgiste au Travail: Une Voie vers le Désengagement Psychologique et la Retraite des Infirmières D'expérience? Revue Internationale de Psychologie Sociale 2010, 23, 91-121. Available online: https: / www.cairn.info/revue-internationale-de-psychologiesociale-2010-4-page-91.htm (accessed on 17 May 2018).

62. Marbot, E. Vers une autre approche de la gestion des fins de carrière? Manag. Avenir 2006, 1, 199-217. [CrossRef]

63. Fournier, G.; Gauthier, C.; Zimmermann, H. Vers une définition du sentiment d'intégration professionnelle: Le cas des travailleurs et travailleuses de 45 ans et plus en situation d'instabilité d'emploi. Revue Canadienne de Counseling et de Psychothérapie/Can. J. Couns. Psychother. 2011, 45, 280-305.

64. Berger, E.D. 'Aging' identities: Degradation and negotiation in the search for employment. J. Aging Stud. 2006, 20, 303-316. [CrossRef]

65. Berger, E.D. Managing age discrimination: An examination of the techniques used when seeking employment. Gerontologist 2009, 49, 317-332. [CrossRef] [PubMed]

66. Blustein, D.L.; Kozan, S.; Connors-Kellgren, A. Unemployment and underemployment: A narrative analysis about loss. J. Vocat. Behav. 2013, 82, 256-265. [CrossRef]

67. Arvey, R.D.; Harpaz, I.; Liao, H. Work centrality and post-award work behavior of lottery winners. J. Psychol. 2004, 138, 404-420. [CrossRef] [PubMed]

68. Bal, P.M.; Kooij, D. The relations between work centrality, psychological contracts, and job attitudes: The influence of age. Eur. J. Work Organ. Psychol. 2011, 20, 497-523. [CrossRef]

69. Tziner, A.; Ben-David, A.; Lior Oren, L.; Sharoni, G. Attachment to work, job satisfaction and work centrality. Leadersh. Organ. Dev. J. 2014, 35, 555-565. [CrossRef]

70. Fournier, G.; Zimmermann, H.; Gauthier, C.; Masdonati, J. L'expérience du chômage chez les travailleurs seniors: De la crise identitaire à la réflexion sur l'avenir. L'Orient. Sc. Prof. 2014, 43, 337-366. [CrossRef]

71. Burnay, N. Chômeurs en fin de Parcours Professionnel. Avoir 50 ans, être au Chômage; Delachaux et Niestlé: Paris, France, 2010; ISBN 9782603012369.

72. Shorikov, V.B.; Vondracek, F.W. Occupational Identity. In Handbook of Identity Theory and Research; Schwartz, S.J., Luyckx, K., Vignoles, V.L., Eds.; Springer: New York, NY, USA, 2011; pp. 693-714, ISBN 978-1-4419-7988-9.

73. Dumora, B.; Aisenson, D.; Aisenson, G.; Cohen-Scali, V.; Pouyaud, J. Les perspectives contextuelles de l'identité. L'Orient. Sc. Prof. 2008, 37, 387-411. [CrossRef]

74. Vignoles, V.L.; Schwartz, K.; Luyckx, K. Introduction: Toward an integrative view of identity. In Handbook of Identity Theory and Research; Schwartz, S.J., Luyckx, K., Vignoles, V.L., Eds.; Springer: New York, NY, USA, 2011; pp. 1-27, ISBN 978-1-4419-7988-9.

75. Grote, G.; Raeder, S. Careers and identity in flexible working: Do flexible identities fare better? Hum. Relat. 2009, 62, 219-244. [CrossRef]

76. FAME Consortium. Vocational identity in theory and empirical research: Decomposing and recomposing occupational identities-A survey of theoretical concepts. In Identities at Work; Brown, A., Kirpal, S., Rauner, F., Eds.; Springer: New York, NY, USA, 2007; pp. 13-44, ISBN 978-1-4020-4989-7. 
77. Osty, F. Le désir de Métier: Engagement, Identité et Reconnaissance au Travail; Presses Universitaires de Rennes: Rennes, France, 2008; ISBN 9782868477606.

78. Baruch, Y.; Cohen, A. The dynamics between organisational commitment and professional identity formation at work. In Identities at Work; Brown, A., Kirpal, S., Rauner, F., Eds.; Springer: New York, NY, USA, 2007; pp. 241-260, ISBN 978-1-4020-4989-7.

79. Dubar, C. La crise des identités professionnelles. In La Crise des Identités: L'interprétation D'une Mutation, 4th ed.; Presses Universitaires de France: Paris, France, 2010; pp. 95-128, ISBN 9782130583653.

80. El Akremi, A.; Sassi, N.; Bouzidi, N. Rôle de la reconnaissance dans la construction de l'identité au travail. Relat. Ind./Ind. Relat. 2009, 64, 662-684. [CrossRef]

81. Brand, J.E.; Levy, B.; Gallo, W.T. Effects of layoffs and plant closings on depression among older workers. Res. Aging 2008, 30, 701-721. [CrossRef] [PubMed]

82. Gutierrez, I.A.; Michaud, P.-C. Whistle while you Work: Job Insecurity and Older Workers' Mental Health in the United States. Cahier de Recherche/Working Paper, 17-02, Octobre; Chaire de Recherche Industrielle Alliance sur les Enjeux Économiques des Changements Démographiques, 2017. Available online: https:/ / www.cedia.ca/sites / cedia.ca/files/cahier_17_02_job_security_older_workers_mental_health.pdf (accessed on 18 May 2018).

83. Mendenhall, R.; Kalil, A.; Spindel, L.J.; Hart, C.M.D. Job loss at mid-life: Managers and executives face the "new risk economy". Soc. Forces 2008, 87, 185-209. [CrossRef]

84. Philips Lassus, L.A.P.; Lopez, S.; Roscigno, V.J. Aging workers and the experience of job loss. Res. Soc. Stratif. Mobil. 2015, 41, 81-91. [CrossRef]

85. Gabriel, Y.; Gray, D.E.; Goregaokar, H. Temporary derailment or the end of the line? Manager coping with unemployment at 50. Organ. Stud. 2010, 31, 1687-1712. [CrossRef]

86. Gabriel, Y.; Gray, D.E.; Goregaokar, H. Job loss and its aftermath among managers and professionals: Wounded, fragmented and flexible. Work Employ. Soc. 2013, 27, 56-72. [CrossRef]

87. Lefrançois, C. Saisir les Aspirations à la Retraite de Chômeurs en fin de Carrière: Enseignements D'une Comparaison France-Royaume-Uni. Retraite Société 2016, 73, 43-63. Available online: https: / www.cairn. info/revue-retraite-et-societe-2016-1-page-43.htm (accessed on 18 May 2018).

88. McVittie, C.; McKinlay, A.; Widdicombe, S. Passive and active non-employment: Age, employment and the identities of older non-working people. J. Aging Stud. 2008, 22, 248-255. [CrossRef]

89. Oakland, J.; MacDonald, R.A.; Flowers, P. Re-defining 'Me': Exploring career transition and the experience of loss in the context of redundancy for professional opera choristers. Music. Sci. 2012, 16, 135-147. [CrossRef]

90. Sweet, S.; Meiksins, P. Changing Contours of Work: Jobs and Opportunities in the New Economy, 2nd ed.; Sage Publications: Thousand Oaks, CA, USA, 2013; ISBN 978-1483358253.

91. Riach, K.; Loretto, W. Identity work and the 'unemployed' worker: Age, disability and the lived experience of the older unemployed. Work Employ. Soc. 2009, 23, 102-118. [CrossRef]

92. Ranzijn, R.; Carson, E.; Winefield, A.H.; Price, D. On the scrap-heap at 45: The human impact of mature-aged unemployment. J. Occup. Organ. Psychol. 2006, 79, 467-479. [CrossRef]

93. Masdonati, J. Préface. In Les Transitions Professionnelles: Nouvelles Problématiques Psychosociales; Olry-Louis, I., Vonthron, A.-M., Vayre, E., Soidet, I., Eds.; Dunod: Paris, France, 2017; pp. 9-16, ISBN 978-2100770021.

94. Parkes, C.M. Psycho-social transitions: A field for study. Soc. Sci. Med. 1971, 5, 101-115. [CrossRef]

95. Baubion-Broye, A.; Hajjar, V. Transitions psychosociales et activités de personnalisation. In Événements de vie, Transitions et Construction de la Personne; Baubion-Broye, A., Ed.; Érès: Saint-Agne, France, 1998; pp. 17-43, ISBN 9782865865734.

96. Fouad, N.A.; Bynner, J. Work transitions. Am. Psychol. 2008, 63, 241-251. [CrossRef] [PubMed]

97. Masdonati, J.; Zittoun, T. Les transitions professionnelles: Processus psychosociaux et implications pour le conseil en orientation. L'Orientation Scolaire Professionnelle 2012, 41, 229-253. [CrossRef]

98. Balleux, A.; Perez-Roux, T. Transitions professionnelles. Rech. Form. 2013, 74, 101-114. [CrossRef]

99. Dupuy, R.; Le Blanc, A. Enjeux axiologiques et activités de personnalisation dans les transitions professionnelles. Connexions 2001, 76, 61-79. [CrossRef]

100. Martin-Canizarès, C.; Mègemont, J.-L.; Dupuy, R. Approche systémique et interindividuelle des rapports travail/hors travail: Rôle des processus de reconnaissance dans une situation de reconversion professionnelle. Prat. Psychol. 2009, 15, 255-270. [CrossRef] 
101. Goodman, J.; Schlossberg, N.; Anderson, M. Counseling Adults in Transition, 3rd ed.; Springer Publishing: New York, NY, USA, 2006; ISBN 978-0826106353.

102. Savickas, M.L. The theory and practice of career construction. In Career Development and Counseling, 1st ed.; Brown, S.D., Lent, R.W., Eds.; Wiley: Hoboken, NJ, USA, 2005; pp. 42-70, ISBN 978-1-118-06335-4.

103. Solove, E.; Fisher, G.G.; Kraiger, K. Coping with Job Loss and Reemployment: A Two-Wave Study. J. Bus. Psychol. 2015, 30, 529-541. [CrossRef]

104. Boutinet, J.-P. L'espace contradictoire des conduites à projet: Entre le projet d'orientation du jeune et le parcours atypique de l'adulte. L'Orientation Scolaire Professionnelle 2007, 36, 19-32. [CrossRef]

105. Guichard, J. Self-constructing. J. Vocat. Behav. 2009, 75, 251-258. [CrossRef]

106. Vondracek, F.W.; Porfeli, E.J. Social contexts for career guidance throughout the world. Developmental-contextual perspectives on career across the lifespan. In International Handbook of Career Guidance; Athanasou, J.A., Van Esbroeck, R., Eds.; Springer: New York, NY, 2008; pp. 209-225, ISBN 978-1-4020-6230-8.

107. Kleschinsky, J.H.; Bosworth, L.B.; Nelson, S.E.; Walsh, E.K.; Shaffer, H.J. Persistence pays off: Follow-up methods for difficult-to-track longitudinal samples. J. Stud. Alcohol Drugs 2009, 70, 751-761. [CrossRef] [PubMed]

108. Fraccaroli, F. Le Changement dans les Organisations; Presses Universitaires de France: Paris, France, 2002; ISBN 978-2-13-052592-9.

109. Creswell, J.W.; Plano Clark, V.L. Designing and Conducting Mixed Methods Research, 2nd ed.; Sage: Thousand Oaks, CA, USA, 2011; ISBN 9781412975179.

110. Sandelowski, M.; Voils, C.I.; Knafl, G. On quantitizing. J. Mixed Methods Res. 2009, 3, 208-222. [CrossRef] [PubMed]

111. Patton, M.Q. Qualitative Research E Evaluation Methods, 4th ed.; Sage: Los Angeles, CA, USA, 2015; ISBN 978-1412972123.

112. Willis, J.W. Foundations of Qualitative Research: Interpretive and Critical Approaches; Sage: Thousand Oaks, CA, USA, 2007; ISBN 978-1412927413.

113. L'Écuyer, R. Méthodologie de L'analyse Développementale de Contenu: Méthode GPS et Concept de Soi; Presses de l'Université du Québec: Québec, QC, Canada, 1990; ISBN 9782760523067.

114. Miles, M.; Huberman, M. Analyse de Données Qualitatives, 2nd ed.; De Boeck Université: Bruxelles, Belgium, 2003; ISBN 9782744500909.

115. Bamberg, M.P.; Creswell, J.W.; Frost, D.M.; Josselson, R.; Levitt, H.M.; Suárez-Orozco, C. Journal article reporting standards for qualitative primary, qualitative meta-analytic, and mixed methods research in psychology: The APA Publications and Communications Board task force report. Am. Psychol. 2018, 73, 26-46. [CrossRef]

116. Creswell, J.W. Educational Research: Planning, Conducting and Evaluating Quantitative and Qualitative Research, 4th ed.; Pearson: Boston, MA, USA, 2012; ISBN 0131367390.

117. Field, A. Discovering Statistics Using SPSS, 3rd ed.; Sage: Los Angeles, CA USA, 2009; ISBN 1847879071.

118. ISQ (Institut de la Statistique du Québec). Revenu D'emploi Médian, 25-64 ans, MRC et Ensemble du Québec, 2005-2015. Available online: http:/ / www.stat.gouv.qc.ca/statistiques/travail-remuneration/populationactive-chomage/mrc/rev_trav_mrc.htm (accessed on 17 May 2018).

119. Virick, M. Underemployment and Older Workers. In Underemployment; Maynard, D., Feldman, D., Eds.; Springer: New York, NY, USA, 2011; pp. 81-103, ISBN 978-1-4419-9413-4.

120. Castel, R. La montée des Incertitudes. Travail, Protection, Statuts de L'individu; Seuil: Paris, France, 2009; ISBN 2020510421.

121. Cohen-Scali, V.; Guichard, J. L'identité: Perspectives développementales. L'Orient. Sc. Prof. 2008, 37, 321-345. [CrossRef]

122. Hattrup, K.; Ghorpade, J.; Lackritz, J.R. Work Group Collectivism and the Centrality of Work A Multinational Investigation. Cross-Cult. Res. 2007, 41, 236-260. [CrossRef]

123. Walsh, K.; Gordon, J.R. Creating an individual work identity. Hum. Resour. Manag. Rev. 2008, $18,46-61$. [CrossRef]

124. Pouyaud, J. For a psychosocial approach to decent work. Front. Psychol. 2016, 7, 422. [CrossRef] [PubMed]

125. Cardoso, P.; Silva, J.M.; Gonçalves, M.M.; Duarte, M.E. Narrative innovation in life design counseling: The case of Ryan. J. Vocat. Behav. 2014, 85, 276-286. [CrossRef] 
126. Maree, J.G. Counselling for Career Construction: Connecting Life Themes to Construct Life Portraits. Turning Pain into Hope; Sense: Rotterdam, The Netherlands, 2013; ISBN 978-94-6209-272-3.

127. Russell, J. The use of narratives to contextualize the experiences and needs of unemployed, underemployed, and displaced workers. J. Employ. Couns. 2011, 48, 50-62. [CrossRef]

128. Van Vianen, A.E.M.; Koen, J.; Klehe, U.C. Unemployment: Creating and conserving resources for career self-regulation. In Handbook of the Life Design Paradigm: From Practice to Theory, from Theory to Practice; Nota, N., Rossier, J., Eds.; Hogrefe Publishing: Boston, USA, 2015; pp. 201-218, ISBN 978-0889374478.

(C) 2018 by the authors. Licensee MDPI, Basel, Switzerland. This article is an open access article distributed under the terms and conditions of the Creative Commons Attribution (CC BY) license (http:/ / creativecommons.org/licenses/by/4.0/). 